\author{
Fr. Janusz Królikowski* \\ UPJPII, Kraków-Tarnów
}

\title{
THE SYMBOL OF FAITH IN THEOLOGY AND IN PREACHING
}

The life of the Church from the very beginning is connected with searching for Her own identity which has its expression in the forming of the profession of faith. The testimonies of this fact can be found already in the Old Testament, which is shown in multifarious doctrinal formulas which are handed over by the apostolic proclamation which is based on them. In a relatively short time these formulas were gathered as a whole, first in the profession of faith used during the right of Baptism and later, especially in a profession of faith which is called the Apostles' Creed. It has preserved its significance and superior role in theology and preaching to this day although in reality its role has been diminished especially in preaching. This paper recommends the return to the Apostles' Creed and to its inspiring role. The most important thing is to present its doctrinal message which highlights the need for the holistic, Trinitarian and Christological perspective in reference to theological issues. Today, the Apostles' Creed can play the same role in the organisation of Church proclamation, which admiring the so called original kerygma falls into short-sighted interpretations and restrictions, resulting in the weakening of Christian identity.

Observing contemporary, or even broader, modern dogmatic theology, it is easy to see that from a formal and structural point of view, the so-called treatises have become its hallmark. They cover the main sections of theology, creating a more or less coherent whole. Much could be said about the various proposals for the systematization of theological treatises put forward even after the Second Vatican Council. In any case, however, it seems that in general their weakness, and this holds true for most cases, is the lack of a closer connection with the

\footnotetext{
Fr. Janusz Królikowski - Priest of the diocese of Tarnów, the dogmatic theologian, profesor at The Pontifical University of John Paul II in Kraków, Facuylty of Theology Section in Tarnów; e-mail: janusz.krolikowski@upjp2.edu.pl; ORCID: 0000-0003-3929-6008.
} 
structure of the creed, and often also with its fundamental option, which could be considered its soteriological significance. This is at odds with the fundamental premise of theology understood as the scientia fidei and scientia salutis. Based on the same self-understanding, theology should strive to organize its contents in such a way that its connection with the creed becomes clear and its existential-soteriological aspect becomes more visible.

While we obviously do not want to take up all possible problems concerning the creed in one place, it seems, however, that the time has also come to deal more dogmatically with the issue of ecclesiastical preaching, in which there is a very similar problem as in theology, namely, a process of ever stronger breaking with the creed under the pretext of so-called kerygmatism. This is obviously not a new problem, although it appears in a new context and with a new justification, obviously as inconsistent as it was in the 1930s and later 1950s in the so-called kerygmatic theology. For over a dozen years now, within the framework of homiletics, as well as in official ecclesiastical documents, we have noted a strange apotheosis of the kerygma, that is, of the so-called first proclamation (preaching), which is undoubtedly a fact in the New Testament, while its proper identification mark and the only tool is to be a homily, treated as a panacea for all defects noticed in ecclesiastical preaching and teaching.

Such a reduction is often justified by reference to the papal teaching, especially of Pope Francis. It must be admitted that its many points are not clear, which is boldly and rightly pointed out. Above all, there is a lack of distinction between the content and the way of teaching. In the Pope Francis' Evangelii gaudium we find this synthetic term for the first proclamation, or kerygma: "Jesus Christ loves you, he gave his life to save you, and now he is alive at your side every day to enlighten, strengthen and liberate you" (No 164). Above all, it should be noted that this is by no means a novelty in ecclesiastical teaching, because already Pope John Paul II, for example, in his exhortation Christifideles laici (30 December 1988), clearly pointed out that this is the principle on which the new evangelization is to be based. We read in this unjustly forgotten document: "Humanity is loved by God! This very simple yet profound proclamation is owed to humanity by the Church. Each Christian's words and life must make this proclamation resound: God loves you, Christ came for you, Christ is for you 'the Way, the Truth and the Life!'." (No 34). Pope John Paul or later Benedict XVI returned to this idea many times, which is not taken into account in various statements.

Many analyses of the Church's teaching on the kerygma would become clearer if, on the basis of classical methodology, a distinction were well made between the material and the formal subject in the statements on the subject. Both the statement of John Paul II and that of Pope Francis concern the subject of formal 
preaching, that is, the perspective that should be given to it, and that perspective is "for you." It is about showing that the content of faith rooted in Jesus Christ has the most personal reference to each person. And this is the right thing to do, both with regard to preaching and with regard to theology, which cannot be an abstract science, but must be concrete with regard to the believer and the one seeking salvation. But ecclesiastical statements do not take sufficient account of the material object of the kerygma, because it is not a concept that can be given a fully unambiguous content. It is certainly about the death, resurrection and ascension of Jesus Christ and the sending of the Holy Spirit as important salvation events, but it is by no means so obvious from an exegetic and theological point of view. As we begin to clarify the issue, it suddenly expands and the assumption of reducing it to a few, even the most important ideas is lost. The supporters of the rigidly conceived kerygma generally aim to limit the scope of the content of the preaching, because they assume that in such a case the preaching will become more effective, which, by the way, has not yet been demonstrated.

The question then arises, simple but extremely fundamental, as to where in this kerygma to place the symbol of faith, or "summary", as St. Augustine called it, of the fundamental truths of the faith ${ }^{1}$. Christian doctrine includes many truths which are essential to ecclesiastical doctrine and which, although they do not belong directly to the original proclamation (kerygma), are irreplaceable in the entirety of faith and ecclesiastical life, such as the truth about creation or original sin. Examples could also be multiplied. Various spiritual and ecclesiastical experiences from different eras confirm that many truths belonging not only to the creed but to Christian doctrine cannot be left on the margins of ecclesiastical preaching, just as they cannot be left on the margins of theology. To make such a separation would mean introducing a dichotomy between the first proclamation and the creed, between the New Testament and the doctrine of the Church, that is, simply between preaching and the catechism. Sooner or later, such a dichotomy would lead to the whole structure of ecclesiastical life being disturbed.

\section{"SYMBOL" - THE ORIGINAL MEANING OF THE TERM}

In ancient times, in order to recognize two counterparties, an object, e.g. a coin, was broken into two parts; each person received one of them, and when the two parts fitted together (symballein), the identity of the shareholders of the contract was confirmed, and thus the contract could be finalized. The symbol, in the ancient sense,

Augustyn, Sermo 213, 1. 
was therefore a sign of conformity, a hallmark, and thus also a sign of unity. In the fourth century, Latin Africa began to call the formula of Christian creed a "symbol" - a single, common symbol of faith was a means of recognizing members of the same community of believers, and at the same time distinguishing true Christians from those who in various ways departed from the true faith, that is, those who had already ceased to be associated with it. In modern use, the term "symbol of faith" has lost its ancient meaning, becoming rather a manifestation of personal faith, or even, in a sense, a doxology since it was included in the Christian's daily prayers ${ }^{2}$.

The official symbols - the creeds can be divided into two categories; the first one includes the "Apostolic Symbol" (Apostolic Creed, "Apostolic Composition", as we traditionally still call it in Polish), including its numerous variants ${ }^{3}$, and the second category includes the council creeds, which are primarily distinguished by their more developed content ${ }^{4}$.

\section{HISTORICAL DEVELOPMENT}

The creeds belonging to both categories have been developed over a long period of time, which shows both their nature and their importance in the life of the Church. In order to speak of a symbol of faith and to seek further opportunities for its use, both in personal and communal faith, as well as in theology and other forms of teaching, especially in preaching, one must bear in mind its historical character.

\section{THE APOSTOLIC CREED}

From the fourth ${ }^{5}$ to the fifteenth and even up to the sixteenth century it was commonly accepted in the Latin Church that the twelve articles contained in the

2 On the various theological and cultural aspects of the Apostolic Symbol cf. Symbol Apostolski w nauczaniu i sztuce Kościoła do Soboru Trydenckiego, ed. R. Knapiński, Lublin 1997; Credo in Deum w teologii i sztuce Kościołów chrześcijańskich, ed. R. Knapiński, A. Kramiszewska, Lublin 2009.

3 Cf. H. de Lubac, La foi chrétienne. Essai sur la structure du Symbole des Apôtres, Paris 1970².

4 On the development of the faith, especially Nicene-Constantinopolitan cf. J.N.D. Kelly, Early Christian Creeds, London 1960²; G.L. Dosetti, Il simbolo di Nicea e di Costantinopoli. Edizione critica, Roma-Freiburg-Basel-Barcelona-Wien 1967; R. Staats, Glaubensbekenntnis von Nizäa-Konstantinopel: historische und theologische Grundlagen, Darmstadt 1996.

5 Ambrose, Epistula (to Pope Siricius) 15*, 5: „But if you do not believe in the teachings of the bishops [...] let them believe the apostolic profession of faith, which the Church of Rome has guarded and preserved intact at all times". 
creed were personally edited by the Apostles ${ }^{6}$. There was even an assignment of each article to individual Apostles. For the first time the questioning of the historicity of this well-established concept came from the East, namely during the Florentine Council, Mark of Ephesus (c. 1394-1444) 7 noted that the Eastern Church knew nothing about the Apostolic Symbol ${ }^{8}$. Later, the humanists, especially Lorenzo Valla, Reginald Pecock and Erasmus of Rotterdam, put the question of the origins of the "Apostolicum" back on the agenda, but it was only in the $19^{\text {th }}$ century that extensive and analytical research on the subject was undertaken, just as was the case with the research into the history of other creeds. A separate field of historical and theological research called "Symbolforschung" was even created, and its important effect is the identification of the various creeds used in different Churches and traditions?.

Since then, in the light of the results of studies - very often openly regarded as sensational - all relations between the symbol and the apostolic era had to be rethought. In these studies, it is relatively easy to go back to the third century, because in the earlier period, everything is very confusing, mainly because of a lack of sources. In any case, however, on the basis of this research, an important conclusion has been drawn, namely, that even if the Apostolic Symbol is later than the Apostolic Age, it is still in direct contact with the creeds found in the New Testament, and even, as is worth noting in today's circumstances, it is a systematic reflection of apostolic preaching, the so-called kerygma. As for the content and form, the "Apostolicum" is truly apostolic because it reflects the tradition of apostolic faith, the prehistory of which can be traced back to the time before the formulas of faith well known from the New Testament appeared.

a) If we look at Acts and reflect on the preaching of St. Peter (Acts 2:14-39; 3:12-26; 4:9-12; 10:34-43) and St. Paul (Acts 13:16-41), it is reasonable to think that it reflects the classic pattern of missionary proclamation during the apostolic period - we find that there is a constant return of certain specific formulas relating to the death, resurrection and ascension of Christ. In addition to the proclamation of the central event of the Passover of Christ, there are also typical expressions of the mysteries that prepare or result from the Paschal event. At Baptism, Christ was pro-

6 St. Thomas Aquinas refers to this tradition in In III Sententiarum d. 25, q. 1, a. 2, but does not mention it in Summa theologiae.

7 Cf. R. Sawa, Marek z Efezu, w: Encyklopedia katolicka, vol. 11, Lublin 2006, c. 1267-1269.

8 Cf. J. Hardouin, Acta conciliorum et epistulae decretales, vol. 9, Paris 1714, p. 842A-843E.

9 Cf. S. Bäumer, Das Apostolische Glaubensbekenntnis, Mainz 1893: C. Blume, Das Apostolische Glaubensbekenntnis, Freiburg 1893; F. Kattenbusch, Das Apostolische Symbol, vol. 1-2, Leipzig 1894-1900; A. Hahn, G.L. Hahn, Bibiothek der Symbole und Glaubensregeln der alten Kirche, Breslau 1897³; J. de Ghellinck, Les recherches sur les origines du Symbole des Apôtres, Paris $1949^{2}$. 
claimed the Messiah (Acts 10:37-38); He revealed Himself through his public life, doing good and miracles (Acts 2:22; 10:38-39); He appeared after the Resurrection (Acts 2:32; 3:15; 5:32; 10:39-42; 13:41) and finally sent his Spirit (Acts 2:23; 5:32).

So we find the whole mystery of the redemption accomplished by Jesus Christ scattered throughout the Acts of the Apostles, always expressed in a certain fixed form that already allows us to think about the future twelve articles of faith. From the very beginning the broad character of the apostolic kerygma and the catechesis of the original Church is revealed, which includes the human, Davidic and messianic origins of Christ (Acts 2:30; 13:33-34), His passion (Acts 3:18), including His rejection by the Jews (Acts 4:11), His resurrection (Acts 2:25-31); 13,34-37), His sitting at the right hand of the Father (Acts 2:34-35), His resurrection as the inauguration of the Messianic times of the Holy Spirit (Acts 2:17-21) and therefore of salvation (Acts $2: 39 ; 4: 12$ ), and the prospect of the Lord's glorious return (Acts 3:20-21). All this calls for conversion, repentance and baptism (Acts 2:38). Certainly we are dealing here with a great synthesis of the guiding lines of apostolic proclamation and thus of the Apostles' creed.

Everything we find in the Acts of the Apostles is clearly confirmed in other New Testament writings, especially in St. Paul. In the apostolic writings similar formulas, often linked to the notion of tradition (paradosis), return repeatedly. St. Paul states very clearly and obligingly at the same time: "I delivered to you as of first importance what I also received" (1 Cor 15:3). It is about the "principle of faith" - the "deposit" of the venerable heritage, which should always be preserved (1 Tim 6:20; 2 Tim 1:14), about the "profession of faith" (Heb 4:14). In the apostolic writings we find the main formulas that will enter the symbol of faith in the future, although they are still scattered: "...by our Lord Jesus Christ, who died for us" (1 Thess 5:10) $)^{10}$; "Jesus indeed died and rose again" (1 Thess 4:14) $)^{11}$; "Christ Jesus, who died, yes, who was raised from the dead, who is at the right hand of God, who indeed intercedes for us" (Rom 8:34) ${ }^{12}$; "Christ died and lived again, that he might be Lord both of the dead and of the living" (Rom 14:9).

In addition to these already established kerygmatic formulas, we also find in the New Testament more official and concrete creeds, which are used for baptism and liturgical celebrations. The practice of confessing the faith in Christ at the time of Baptism was established very early on (Acts 22:16; 8:37), simply becoming the norm ${ }^{13}$. In addition, there also appear very clearly defined confessions of faith, for example, during exorcisms or miraculous healings. A characteristic

10 Cf. Rom 4:25; 2 Cor 5:14; Ga 1:4; 2,20 etc.

11 Cf. Rom $4: 25 ; 8: 34 ; 14: 9$ etc.

12 Cf. Eph 1:20; Heb 1,3,13; 8:1; 10:12; 12:2; 1 P 3:22.

13 Cf. Acts $2: 38 ; 8: 16 ; 10: 48 ; 19: 5 ; 1$ Cor 1:13-15; Matt 28:19. 
feature is the confession of faith made at the time of persecution (1 Cor 12:3; Rom 10:9) and generally at liturgical gatherings ${ }^{14}$.

The creeds typical of the New Testament are of Christological character. There are also two-part professions of faith in which the Father is mentioned together with his Son, Jesus Christ. It cannot be ruled out that such creeds were introduced as part of the preaching addressed to the Jews, who had to be offered monotheism in connection with the mystery of Christ. ${ }^{15}$ Finally, the New Testament also contains the first creeds of the Trinitarian faith, or at least the first ones that generally include the Three ${ }^{16}$. The addition of the Holy Spirit to the confessions of the Father and the Son seems to be a direct result of the rapidly maturing liturgy of baptism, which aims to show that the baptized person is included in the fullness of the Christian faith, realized in a personal and direct reference to the Father, the Son and the Holy Spirit. To emphasize the link between the paschal event of Jesus Christ and the message of the Holy Spirit, St. Paul could refer to the baptismal event. We find in him a pattern based on the reference to the Three, especially when he takes up the baptismal theme. It is therefore certain that in addition to the creeds of a Christological character, there are also formulas of a Trinitarian character in the New Testament.

b) Starting from these Christological and Trinitarian creeds that we meet in the New Testament, two different formulas, that is, Christological and Trinitarian, appeared gradually and were applied. They were born independently of one another, in different contexts, but were quickly combined in the baptismal liturgy. It is not possible to determine precisely when this happened, but some testimonies indicate at least in general terms that it could have happened at the turn of the second and third centuries. The fluctuations that emerge during this period become very meaningful.

In St. Justin, the two schemes are sometimes separated ${ }^{17}$, and in other cases they are connected ${ }^{18}$. In St. Iraeneus, the merger of the two formulas has already taken place, although in such a way that the Christological article has been incorporated into the confession relating to the Holy Spirit ${ }^{19}$. In the Apostolic Tradition attributed to St. Hippolytus ${ }^{20}$ and to Tertullian we find the first testimonies of the

14 Cf. 1 Cor 16:22; Col 3:6; Phl 2:6-11; 4:5.20; 1 Tim 3:16; 1:17; Rom 11:36; 16:27.

15 Cf. 1 Tess 2:16; 1 Cor 8:6; 2 Cor 1:3; 11:31; Eph 1:3; Acts 4:24-30; Col 3:16-17; 1 Tim 6:13; 2:5; 2 Tim 4:1; 1 P 4:11; Rev 1:2.

16 Cf. Matt 28:19; 2 Cor 13:13; Acts 5:29-32. Moreover, the following can be indicated: Gal 4:4-6; 1 Cor $6: 11 ; 12: 4-6$; Eph $1: 3-14 ; 2: 18 ; 1$ P 1:2-12.

17 Cf. Justin, 1 apologia. 13, 3-4.

18 Cf. Justin, 1 apologia $61,3$.

19 Cf. Iraeneus, Adversus haereses 1, 10, 1.

20 Cf. DH 10; BF (2007) 4 
merger, which will later take precedence, in which the Christological article is the second and gradually expanding part of the Trinitarian symbol. Since this synthetic symbol was also a baptismal symbol, it took on a dialogical form. The confession of faith in its personal form ("credo - I believe") will appear later, especially in St. Rufinus of Aquileia ${ }^{21}$. It is a "Roman formula"22 of the Apostolic Symbol. Given that the Hippolytus' Tradition reflects the Roman liturgy of about 215, the baptismal symbol contained therein is indeed the most original formula of the present symbol. However, its general scheme must be even older, that is, it must be situated at the beginning of the second century, as shown by the allusions we find in St Ignatius of Antioch, Tertullian and St. Iraeneus. The liturgical papyrus of Dêr Bazyleh in Upper Egypt conveys an even older symbol which, in its simple form, has the same structure as the baptismal symbol of Hippolytus: "I believe in God the Father Almighty, and in his only-begotten Son, our Lord Jesus Christ, and in the Holy Spirit, and in the resurrection of the body in the holy Catholic Church"23. We can therefore conclude that the basic form of our Apostolic Symbol appeared at the end of the second century probably in Rome.

c) The current version of the Apostolic Symbol, classical throughout the West, which has entered our catechisms and thus also our preaching, and which is also used in the administration of the sacraments, was first found in Ordo Romanus in 950. It was called "textus receptus" 24 . It has no Roman origins, but most likely comes from southern Gaul; however, we find it in certain variations at the turn of the fourth and fifth centuries. It is actually already present in the Gelasian Sacramentary ${ }^{25}$. During the Carolingian reform it came to Rome. The Roman symbol in Greek in intermediate form between the $\mathrm{R}$ and $\mathrm{T}$ versions was included in Marcel of Ancyra's letter to Pope Julius ${ }^{26}$.

d) We still have even less information about the eastern symbols. Actually, in the main themes they have been formed in the same way, but they have taken on more elaborate and detailed forms, as well as more varied. Certainly, this was influenced by numerous doctrinal controversies, which appeared with strong clashes in the East. We know the baptismal symbols of numerous local churches,

${ }^{21}$ DH 12. Cf. V. Peri, Rufino e il simbolo della Chiesa di Aquileia. La tradizione culturale del Simbolo Apostolico nella "stilizzazione storica" occidentale, w: idem, Da Oriente e da Occidente. Le Chiese cristiane dall'impero romano all'Europa moderna, a cura di M. Ferrari, vol. 2, Roma-Padova 2002, p. 750-778 [Medioevo e Umanesimo 108]. "Forma Romana", called version R, is also called "forma occidentalis antiquior". Cf. DH 10. $\mathrm{DH} 2$.

It is also called version T or "forma occidentalis recentior". Cf. DH 30.

DH 36; BF (2007) 12.

PG 42, 385. 
such as the Palestinian Caesarea ${ }^{27}$, Jerusalem ${ }^{28}$, Antioch ${ }^{29}$ etc., dating from the $4^{\text {th }}$ century.

e) Although the symbol of faith which has taken on the classic meaning, was not put together by the Apostles, it can be called "apostolic" in a consistent and rightful way. It has been rightly stated in the Catechism of the Catholic Church: "The Apostolic Symbol was named this way because it is rightly considered a faithful summary of the Apostles' faith" ${ }^{30}$. It is indeed the "rule of faith" which stems from the Apostles' original proclamation, drawn from their personal encounter with Jesus Christ and the experience of faith based on it. It is not only a faithful reflection of the original "kerygma," but also its first and binding synthesis. This is why it defined the shape of the apostolic catechesis addressed to the neophytes as well as the faith of the Church, which would then be supplemented and developed, but would always retain this original centre. There is therefore no basis to introduce any division between apostolic preaching and the ecclesiastical clarification of its doctrinal principles, the most important manifestation of which are the confessions of faith, because at their starting point these two areas of ecclesial life form an organic unity.

$* * *$

The twelve articles of faith contained in the Apostolic Symbol (version T) have never been solemnly dogmatized in the Church, although it must be made clear that it has always been treated as a general rule of faith, accepting its contents in ordinary and universal teaching, indicating it as a certain point of reference for individual believers and for the ecclesiastical religious formation, which is also reflected in his elevation in the Catechism of the Catholic Church, which based its lecture on the doctrine of the faith on this symbol, complementing it with some of the statements contained in the Nicene-Constantinopolitan Symbol ${ }^{31}$.

So if we are talking about the Apostolic Symbol, we have to keep in mind that it is a kerygmatic-dogmatic symbol, although genetically and functionally it is a baptismal symbol. The principle "lex orandi - lex credendi" has found full application in it, emphasizing that the Catholic creed is deeply rooted in the living devotion of the Church and above all in her liturgy, that is, in the essential manifestation of her life and her identity. If, therefore, one wants to form Catholic devotion, to revive the liturgical spirit and to form the basis of commitment in the spirit of the Gospel, it is not enough to refer to the original kerygma, but one

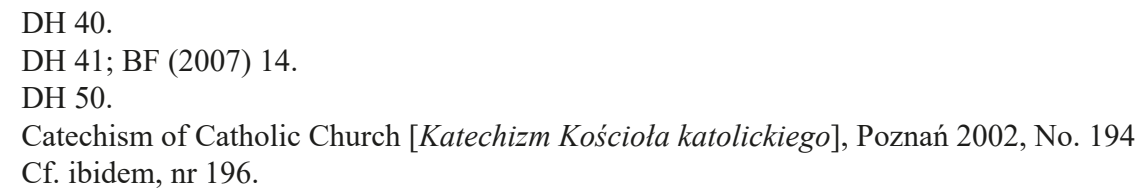


must clearly and decisively appreciate the faith described in the articles of the Apostolic Symbol.

Although the symbol of faith is a baptismal symbol, which was initially to be confessed by a neophyte at the time of baptism and was later to serve as a reference point for formation to the Christian life, it cannot be considered as some complete extract of Christian dogmas. It only takes into account the main truths of the creed which the Church demands from the catechumen. This explains why a reality as important as the Eucharist, for example, is not mentioned in it. It only concerns initial initiation, and so many themes that arise in the formation of neophytes after Baptism, and also in the course of the developing Christian life, are not included.

As the history, and especially the prehistory of the Apostolic Symbol was not known, it was treated during the Middle Ages as a complete but synthetic articulation ("articulus") of faith on which all dogmas were based. It was believed that the symbol was some kind of pre-foundation from which they grew up, as well as their existential orientation. St. Thomas Aquinas is also the heir to this premise on which he built his concept of the "article of faith", even though be he included in it some innovative contents, departing from the traditional understanding of the Apostolic Symbol ${ }^{32}$. According to Aquinas, articles of faith are dogmatic, not because they are connected with the original apostolic symbol of faith, but because they have a salvific character which allows to shed the right light also on all theological issues, including the identification of certain truths as dogmas. A dogma, then, is something that cannot be rejected if one is to guarantee salvation for man. This approach reflects the idea that dogma and theology show their proper meaning in a soteriological perspective (scientia salutis). It is a conception that refers to the patristic tradition, although it contains some additions, because the Fathers of the Church saw in the soteriological perspective first of all the principle of defending the doctrine of faith, while the approach of St. Thomas is more open, which allows him to include all theology in this principle. In this perspective, all the theological content is placed in such a way that it refers to the individual man, showing him how God works for his salvation. In the further part of the part we will return to the concrete consequences of St Thomas Aquinas' concept.

\section{CONCILIAR AND SYNODAL SYMBOLS}

In a certain contrast to the simplicity of the Apostolic Symbol, there are symbols (confessions) of faith proclaimed by the universal councils, as well as by par-

32 Cf. Thomas Aquinas, Summa theologiae II-II q. 1, a. 6-9. 
ticular synods. These are, above all, more elaborate depending on which doctrinal problems, in the concrete circumstances of ecclesiastical life, were attempted to be answered through them. With these confessions there has inevitably been a certain "theologization" of the baptismal profession of faith, which, however, should not be considered only negatively, as is sometimes done. They are an expression of a willingness to defend the truth and, above all, a manifestation of the maturity of faith and the richness of its expressions in the Church, and sometimes of its doctrinal-theological pluralism. At least in the beginning these symbols remained outside the context of liturgical and catechetical life, and their immediate aim, starting with the Apostolic Symbol, was generally to combat heresy. None of the creeds proclaimed in the Church proved superfluous.

Among the conciliar symbols, "fides nicaena," i.e. the confession of faith of the First Council of Nice of 325, ranks absolutely first ${ }^{33}$. Its starting point is the eastern version of the Apostolic Symbol, worked out from the perspective of the Arian heresy countered by the Council.

The Nicaeno-Constantipolitanum symbol is a reworked version, certainly related to the First Council of Constantinople (381), the Eastern Apostolic Symbol and the Nicean Symbol ${ }^{34}$. Its genesis is still uncertain, which is ultimately not the most important thing; the decisive factor is that it reflects ecclesiastical orthodoxy - especially in the version promoted by Saint Basil the Great ${ }^{35}$ - which was highlighted in the context of Christological and Pneumatological disputes in the middle of the fourth century, making this symbol very quickly and universally accepted in the East. In the doctrinal context, the Nicene-Constantinopolitan symbol appeared for the first time during the Council of Chalcedon in 451, at which the fathers stated that in the announced adapted definition of the faith they also wanted to preserve "the symbol of the one hundred and fifty Holy Fathers gathered in Constantinople" ${ }^{" 36}$. The scarce sources concerning the First Council of Constantinople do not allow much to be said about the genesis of this symbol. It is certain that it appears in 374 in Epiphanius of Salamis ${ }^{37}$ and that it is connected with the Church of Jerusalem and its baptismal tradition.

3 DH 125; BF (2007) 30.

34 DH 150; BF (2007) 36.

35 Cf. J.-R. Pouchet, Vivre la communione dans l'Esprit Saint et dans l'Église. Études sur Basile de Césarée, Abbaye de Bellefontaine 2014, p. 241-330.

36 Council of Chalcedon [Sobór Chalcedoński], Definicja wiary 5, in: Dokumenty soborów powszechnych, vol. 1: Nicea I, Konstantynopol I, Efez, Chalcedon, Konstantynopol II, Konstantynopol III, Nicea II (325-787), ed. A. Baron, H. Pietras, Kraków 2001, p. 217 [Źródła Myśli Teologicznej 24].

37 DH 44. 
The Nicene-Constantinopolitan symbol was included in the liturgy of the Mass. ${ }^{38}$ This practice was initiated in Constantinople, to which Patriarch Timothy (511-517), associated with the monophysite community, probably contributed, thus intending to officially introduce his orthodoxy. In the East, the practice was widely accepted, from where it passed to Spain in 589. In the ninth century, we find this creed in the Frankish countries, which happened with the contribution of Charlemagne. Then the practice gradually spread to the northern countries. When Emperor Henry II came to Rome in 1014, he was surprised that the creed was not recited during Mass. Pope Benedict VIII (1012-1024) granted the emperor's request, and in this way the symbol from the East was incorporated into the Roman Mass. Later on, it was accepted as a profession of faith by the Council of Trent and was long used in the Church as the official profession of faith ${ }^{39}$. Since the NiceneConstantinopolitan symbol was adopted by the Councils of Chalcedon and Trent as their fundamental doctrinal premise and is part of the Eucharistic celebration, it is undoubtedly dogmatic in nature. It is also necessary to remember the dogmatic definition introduced by the Council of Chalcedon, which must be taken in conjunction with the whole symbol of faith ${ }^{40}$.

Later on, many creeds appear, proclaimed by universal councils and local synods. An important role in the Church was played by the symbol of the XI Synod of Toledo $(675)^{41}$, which proclaimed the teaching on the Trinity; it certainly contains an authentic explanation of dogma, but it was not approved by Pope Innocent III (1198-1216), as it was sometimes thought ${ }^{42}$. The Quicumque symbol is worth mentioning ${ }^{43}$, which was originally edited in Latin and certainly cannot be attributed to St. Athanasius, as was believed for centuries. Although as yet little can be said about its origin, it is a very interesting theological and spiritual phenomenon. The use of this creed in liturgy, at first private, but over time also official, determines its dogmatic value. It seems to belong to the category of anti-Priscillan symbols that appeared in Spain, such as Fides Damasi ${ }^{44}$ or Clemens Trinitas $^{45}$. Certainly worth mentioning are also: the creed of the Fourth Lateran

38 Cf. J. Królikowski, Miejsce i znaczenie wyznania wiary w liturgii, „Analecta Cracoviensia” 49 (2017), p. 67-80.

39 DH 1862-1870; BF IX, 40-46.

40 DH 301-302; BF (2007) 89.

41 DH 525-541; BF (2007) 171-197.

42 Cf. J. Madoz, Le symbole du XI ${ }^{e}$ concile de Tolède. Ses sources, sa date, sa valeur, Louvain 1938, p. 161-162.

43 DH 75-76; BF (2007) 122.

44 DH 71-72; BF (2007) 20.

45 DH 73-74; BF (2007) 21. 
Council (1215) against the Albigenses and Cathars ${ }^{46}$; the creed of Pope Leo IX (1049-1054) ${ }^{47}$, later included in the creed of Emperor Michael Palaeologus during the Second Council of Lyons $(1274)^{48}$; the already mentioned Tridentine creed with additions made by Pope Pius IX and the fathers who came to the First Vatican Council $(1870)^{49}$. Certainly, the anti-modernist oath of 1910 should also be mentioned here, although it does not constitute a confession of faith in the strict sense. However, by being emphasized, it had a significant impact on preaching, and some of its formulations still affect theology, at least some of its treatises, especially the theology of revelation and ecclesiology ${ }^{50}$.

The 1968 "Credo Populi Dei - Confession of Faith of the People of God" ${ }^{51}$ of Pope Paul VI deserves special attention, although surprisingly, it does not enjoy any greater recognition in contemporary theology or in devotion ${ }^{52}$.

\section{THEOLOGICAL REFLECTIONS}

A review of the various issues concerning the history of the Apostolic Symbol and other symbols in the Church now leads to at least a few suggestions for theology and preaching, because it is clear that the history discussed has been closely connected from the beginning with these areas of Church life.

a) First of all, it should be noted that the Apostolic Symbol has a fundamental and clear soteriological dimension, which implies a very specific vision of salvation. The Holy Trinity reveals its inner life and itself as the Saviour of man in history and through the history of salvation initiated with creation, reaching its fulfilment in Jesus Christ, God-Man, and its completion occurs in eternal life. It is true that Christological confessions are more frequent in the New Testament, but unacceptable is the thesis of Oscar Cullmann ${ }^{53}$, which is also repeated today, both in the theology and in the theology of the preaching, according to which

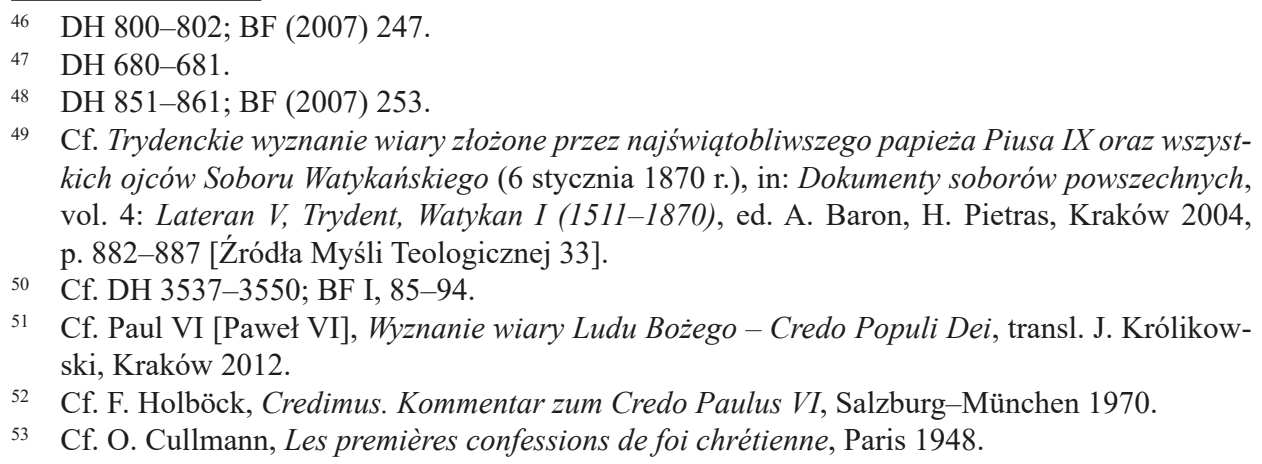

51 Cf. Paul VI [Paweł VI], Wyznanie wiary Ludu Bożego - Credo Populi Dei, transl. J. Królikowski, Kraków 2012.

52 Cf. F. Holböck, Credimus. Kommentar zum Credo Paulus VI, Salzburg-München 1970.

53 Cf. O. Cullmann, Les premières confessions de foi chrétienne, Paris 1948. 
the transition from Christological confessions to Trinitarian confessions would be some kind of deviation connected with post-apostolic times, which contributed to depriving Christianity of its Christological authenticity. It is evident that already in the New Testament the mystery of Jesus Christ is inseparably connected with monotheism and theocentrism of the Old Testament. The event of salvation is treated starting from the providential rule of God the Father, who rules over creation, constantly directs the history of salvation, and Jesus Christ also turns to Him completely in his life and in his actions.

Everything begins with creation, which then continues through God's salvific works in the old covenant. The reference to the biblical vision of faith, which inseparably links creation and covenant - being a kind of personal development of the mystery of creation - to which the New Testament explicitly refers, allows this to be said, although the covenant is not explicitly mentioned in the Apostolic Symbol. This concept is therefore present in the first word "I believe" itself, the proper meaning of which we know, among other things, by reference to witnesses to the faith (Heb 11:3-40; Acts 4:24-27). Jesus Christ is the fullness of the mysteries of creation and covenant.

The Father, the Creator, is the source, author and target of the history of salvation, of which Jesus Christ is the personal and working centre: "For of Him and through Him, and for Him is everything." (Rom 11:36). The New Testament treats monotheism and theocentrism as a permanent background for the salvific mystery of Jesus Christ: "in Christ God was reconciling the world to himself" (2 Cor 5:19). Through the Holy Spirit - God - Christ was born (Matt 1:20), in the Spirit He was justified (1 Tim 3:16), and at his descent at baptism in the Jordan He was called the Beloved Son (Lk 3:22). In the power of the Spirit resting on Him, Christ accomplished great works (Acts 10:38), sacrificed Himself on the cross (Heb 9:14), was raised from the dead by His power (Rom 8:11), and was established in power as the Lord and Messiah (Acts 3:13-15). The God of the covenant, who once spoke through the prophets, has now spoken through his Son (Heb 1:1-2), and His voice resounds in the Church, which is His "now" in history.

All this shows that the Christological confessions of faith are inconceivable without their precise location in the Trinitarian context, which in the Apostolic Symbol was clearly formulated on the basis of the fundamental inspiration provided by the original apostolic preaching (kerygma). In this proclamation, in the original catechesis and in the apostolic confessions of faith, the mystery of Jesus Christ is seen in an essential way from the perspective of the mystery of God, which encompasses everything with its radiation. In the original Church, on the other hand, the experience of the works and actions of the Holy Spirit was closely 
linked to the proclamation of the mystery of Christ. The original teaching connects the Holy Spirit's mission with the most important messianic event, which is Christ's resurrection and exaltation in glory (Acts 2:33).

The original apostolic proclamation (kerygma) can therefore be summarized in the following way: on the basis of the resurrection, the Father gives the fullness of the Holy Spirit to Jesus Christ, who, for His part, imparts Him permanently and forever to the whole Church. The history of salvation is the work of the Holy Trinity; it reaches its climax in Jesus Christ, who reveals the Holy Trinity to us as "Deus salutaris - God the Saviour" 54 . This scheme - God's saving initiative realized in Jesus Christ and completed in history by the Holy Spirit - is obviously already present in the Christological opening hymn to the Ephesians (1:3-14). The believers' reflection on the mystery of Jesus Christ, undoubtedly linked to the pneumatological experiences of the young Church, reached its culmination in the first Trinitarian confessions. Although they are still very general, they clearly confirm that the Christian lives authentically as a believer only in his personal relationship with the Three: Father, Son and Holy Spirit.

We find the same theological and spiritual climate in the Apostolic Symbol. Christ, the pre-existing Son of God, sent by the Father in the flesh, entered into the glory of the Father through His resurrection, but by virtue of His personal sacrifice He appears in this glory as a power sanctifying and sending the Holy Spirit to act in the Church, even though He had already spoken through the prophets. This is the profound inspiration that underpins the Apostolic Symbol. Creation, redemption and fulfillment in glory are the three stages in the history of salvation, fulfilled by God, the One and the Triune, manifested in the individual salvific actions realized by the Three. The Apostolic Symbol read in this key is one of the best examples of the identity of the confessions of faith, the prehistory of which is the original apostolic preaching and its summaries made already in the New Testament formulas. The development that would follow was a continuation of this development that met the various historical requirements.

b) The second reflection concerns the fact that in the Holy Scripture "fides fiducialis," that is, the great question of trust in God, is always and fundamentally connected with the profession of faith. In other words, the personal and existential act of faith, as a fundamental choice, is never separated from the "fides dogmatica," in which the personal position is completely determined by the manifested salvific reality. The opposite is also true, namely, the profession of dogmatic faith cannot be separated from the act of existential faith, as the New Testament clearly shows: the faith of the centurion (Matt 8:5-13), the faith of Peter walking on water

54 The Fathers of the Church captured this fact very well in their teaching about God and Jesus Christ. Cf. B. Studer, Gott und unsere Erlösung im Glauben der alten Kirchen, Düsseldorf 1985. 
to Jesus (Mk 14:22-23), or the praise of the faith of the ancestors (Heb 11:4-38). The "object" of the profession of faith concerns not only things and events, even the event of salvation, but also the Person, that is to say, the living God as God for us and with us, as he is revealed in Jesus Christ.

In the faith of the Church, each profession of individual articles belonging to the "Apostolicum" presupposes a fully personal act of faith in the living God. None of its articles have any theoretical character. The ecclesiastical tradition, above all St. Thomas Aquinas, has taken a keen interest in the expression "Credo in unum Deum," 55 which already in its linguistic specificity (neither classical Greek nor Latin knows it) tried to express the full personal dimension of faith. As faith in the living God, the confession of Christ ends ultimately - against the background of the confession of the works of the Holy Spirit concentrated on the forgiveness of sins, that is, on the ecclesiastical sacramental order - in faith in the resurrection of the body and in eternal life. I believe in God the Saviour: the Father, the Son, and the Holy Spirit, who through the saving work of Jesus Christ, in the power of the Holy Spirit, is eternal life for man in body and soul. This is the lasting basis of the confession of faith and the inspiration of every theology and every preaching.

c) Without going into the details of the matter, it is sufficient to point out here that the profession of faith, being based on concrete revealed content, refers in the highest degree to the personal life of those to whom it is addressed and whose answer it demands. In other words, in the perspective of faith, one can say that what inspires the first and fundamental trust in God is His truth. Of course, what reinforces this dependence is the fact that God's truth is never theoretical, but it is an event, it is based on events and it gives rise to events. Thus at the point of departure it has a testimonial character that moves and calls for an answer. Particularly evident is this concept of truth in Saint John, in whom it recurs very often and is almost entirely shown in such a way that it is open to relationship, closeness and reciprocity. God's truth, therefore, is structured in such a way that by its very nature it is intended to inspire confidence, although there is no doubt that the basic task of theology and preaching is to show this fact.

In the light of the biblical concept of faith it is therefore unacceptable to juxtapose the object of faith with an act of faith, as well as juxtapose the "fides fiducialis" and "fides dogmatica." The dichotomy in this regard, which is particularly present in Luther's concept, is an expression of a lack of consideration of what faith is in its biblical sources. Neither in the Old Testament nor in the New Testament is there the slightest basis to justify this. It is quite the contrary, which

55 Thomas Aquinas, Summa theologiae II-II q. 2, a. 2. In this article Aquinas draws attention to three formulas that describe different aspects of faith: "credere Deo, credere Deum, credere in Deum". 
the Psalms prove very suggestively. They are certainly a school of trusting faith, but at the same time no Bible book is as dogmatic. The Psalms are a spiritual synthesis of a heart poured out with trust before God, because they enable the Psalmist to know God. They show that trust in the believer arises only from the knowledge of God working in creation and covenant, i.e. in objective works. It is never based on some kind of inner experience, on the analytical reaching into oneself and one's own depths, nor is it born from thinking about ideas.

d) The problem posed here is meaningful for theology, which should give it consideration. It is a known and evident thing, that the creed is a point of reference for theology, since it is a scientia fidei, that is, it is based on what the Church believes in. The problem, however, does not come down to this simple and rather obvious fact, but it is more about whether the profession of faith, above all the Apostolic Symbol, should also serve to give the proper structure the theological lecture.

In the twentieth century, much attention was paid to studying the structure of the Summa Theologiae of St. Thomas Aquinas, reflecting on its genesis, neoplatonic influences, the pattern of exitus - redditus etc. ${ }^{56}$ However, something simpler was not noticed, namely that it reflects to a large extent the structure of the Apostolic Symbol, which is not Platonic, but profoundly biblical and Christological, which clearly shows that we have come from God and are heading towards God, and this journey becomes possible in Jesus Christ and in the Holy Spirit. There is no coquetry in Aquinas' statement that he addresses his work to "beginners - ad eruditionem incipientium" ${ }^{57}$, just as the Apostolic Symbol is addressed to the beginners.

As already mentioned, the modern and contemporary lecture of theology is based on a system of treatises covering the main fields of theology. A frequent, repeatedly reported negative result of such a shape given to theology is that their mutual bond is lost, and thus the classical assumption that theology is and should be "one science." So, basing the theological lecture on a historically and logically coherent structure of the ecclesiastical creed could therefore contribute to overcoming this negative tendency, which results in the fragmentation of theology.

What could further strengthen the theological lecture and contribute to its further consolidation in terms of content would be to put greater emphasis on its soteriological option, which is the theme of the Apostolic Symbol. It has been stated for a long time that Catholic theology has been marked by a significant so-

56 Cf. M.-D. Chenu, Le plan de la Somme Théologique de S. Thomas, „Revue Thomiste” 45 (139), p. 91-107; A. Patfoort, Thomas d'Aquin, les clés d'une teologie, Paris 1983, p. 49-70; I. Biffi, Teologia, storia e contemplazione In Tommaso d'Aquino, Milano 1995, p. 223-312.

57 Thomas Aquinas, Summa theologiae, I, prologus. 
teriological "deficit." In fact, many theological treatises lack a marked tendency to present a clear and certain way of salvation, which is undoubtedly present in their contents. A more profound rethinking of soteriological problems, which underlie the creed and many dogmatic definitions, could contribute to this. Certainly noteworthy is the above mentioned concept of the article of faith, which is found in St. Thomas Aquinas and which was then transferred to his theology, about which there should be no doubt that it is deeply soteriological. This is not only due to his assumption concerning theology as scientia salutis, but also to the whole of his theological lecture, which consistently takes this into account ${ }^{58}$.

e) In line with the original assumption of this paper, let us turn our attention to the issue of preaching, or actually to one of its currents and a very pronounced one. In today's concept of the kerygma there appears a problem which is actually connected with what we said about "fides fiducialis." Emphasizing the perspective of "God/Jesus Christ for man" - "for you and for me" is undoubtedly right and biblically justified, for God has revealed Himself for the sake of man. Actually, all the teaching and activity of the Church, not just preaching, is based on this conviction. Moreover, it is a perspective that is clearly present in most of the symbols of faith, in which it is affirmed that everything they speak of, not only the incarnation of the Word, has been done "for us and for our salvation." Hans Urs von Balthasar, in his commentary on the creed, stressed: "We never believe in words, but in one single reality that unfolds before us, for us and in us, which is at the same time the highest truth and the deepest salvation" $" 59$. God is anthropocentric in his salvific action in every respect.

So the general assumption of the kerygma and its perspective does not raise doubts, but the same cannot be said of its application. Classically, that is, above all biblically and truthfully, what shows that God's salvific work is "for me" is its actual realization, which then becomes the subject of a narration, aimed at bringing out its truth. In this event-and-truth combination it is best and most clearly shown that God is really working for man - for me. Juan Alfaro, who deeply reflected on faith in the Bible, states: "Faith lives the reality of its object, which is the salvific intervention of God through Christ; if the salvific event of Christ is not real in itself, it cannot be real for me - I cannot experience it as real" ${ }^{160}$. There is no other

58 Cf. Y. Congar, Le sens de l'«Économie» salutaire dans la «théologie» de sant Thomas d'Aquin (Somme theéologique), w: Glaube und Geschichte. Festgabe Joseph Lortz, ed. E. Iserloh, P. Manns, Baden-Baden 1957, p. 73-122.

59 H.U. von Balthasar, Credo. Medytacje o Sktadzie Apostolskim, thum. J. D. Szczurek, Kraków 1997, p. 21.

60 J. Alfaro, La fede come dedizione personale a Dio e come accettazione del messaggio cristiano, "Concilium" [Italian ed.] 3 (1967), p. 69. 
way and means to show this than to recount the truth of God's works, and this is the only way to stimulate man to respond, that is, ultimately, to believe.

In ecclesiastical statements, at the higher and lower levels, there is a repeated call for the kerygma to arouse the "admiration for God", which us supposed to become the basis of faith, its renewal and living it fruitfully in the world today. This statement in itself may not be controversial, but the proposed path to it, which generally boils down to arousing emotions that are considered synonymous with admiration, is unacceptable. Here we are dealing with some kind of spiritual and theological Freudism ${ }^{61}$. The only admiration that can bring something into a person's life is the admiration aroused by God's objective action and by the people who have captured it and translated it into their personal experiences, that is, simply believed, trusted and loved Him. In order to arouse such admiration, it is absolutely necessary to speak first and foremost about God's action and its truth. All in all, only this truth can arouse admiration so that it will then develop into a faithful life. Surely there is something right in the theology trying to act on the basis of the narrative method.

Unfortunately, today's proclamation, above all the kind that is kerygmatically oriented and led by various clerical and lay "evangelizers", to a large extent does not take this fact into account, because it is based on an emotionally stimulated search for some kind of approval for the faith through various miracles, healings, prophecies, visions, etc., which are purported to confirm its authenticity. It refers to the concept of a miracle as a testimony of faith, but in general it is all infested with superficiality, falsehood and pseudo-charismaticism. Still, the greatest miracle is God's action in the history of salvation and its events, which today is prolonged above all by the miracles of conversion and faith realized in many people who do not need a miracle to believe. It is worthwhile to refer to St. Thomas Aquinas, who in his sermons on the Apostolic Symbol made a suggestive observation: "The conversion of the world without a miracle is probably an even greater miracle. So why should we look for another miracle?"62. Perhaps it is also worth remembering the sentence known to many fathers of the Church that the one who converts is greater than the one who resurrects the dead.

The Apostles' symbol and other symbols of faith can also arouse the admiration of God if they are well presented, if one brings out their contents as being "for us and for our salvation", that is "for me". How to do this? This is a separate question, although the essential elements of the answer have already been shown

${ }^{61}$ On the genesis and modern conception of emotions cf. M. Menin, Il fascino dell'emozione, Bologna 2019.

62 Thomas Aquinas [Tomasz z Akwinu], Wyktad Składu Apostolskiego, wstęp, 8, in: idem, Dzieła wybrane, transl. J. Salij et al., Kęty 1999, p. 578. 
above. It certainly cannot be done by separating the preaching and the creed from each other, because both concern the same thing and even are the same thing, differing from a pragmatic point of view, as St Thomas Aquinas already knew ${ }^{63}$. In fact, the only problem today is to find the right language to use to speak about God, because what needs to be said about Him is obvious.

\section{CONCLUSION}

In one of his statements, the great Orthodox theologian Georges Florovskij, pondering over what should be proclaimed to the present generation, wrote: "Of course, I still fully and consciously preserve and accept 'the teaching contained in the creed', because by faith I grasp its constant relevance and meaning for every era and every time, including 'our time'. And I believe that it is precisely the 'teaching contained in the creed' that can enable our generation, immersed in hopelessness, to regain Christian courage and Christian vision of reality" ${ }^{\prime 4}$. Starting from this conviction, Florovskij encourages unambiguously: "Preach the symbols of faith!" ${ }^{65}$. I believe that these statements are deeply justified and their message corresponds with the inspirations that come from the Apostolic Symbol and the apostolic preaching (kerygma). We are, therefore, situated in the framework of a kind of theological feeling which not only cannot be underestimated, but must definitely be adhered to, bearing in mind that we have urgent work to do both in theology and in preaching. We also do not forget that this is our contribution to the creation of culture and to the shaping of concepts that relate to the concrete life situations of modern $\operatorname{man}^{66}$. As we have already mentioned, the truths contained in the symbols of faith have a doctrinal meaning, but they are also truths that speak about man in his earthly condition, so they should also be seen in an earthly perspective, gaining the courage to draw appropriate conclusions from them.

\section{BIBLIOGRAPHY}

Alfaro J., La fede come dedizione personale a Dio e come accettazione del messaggio cristiano, „Concilium” [Italian ed.] 3 (1967), p. 69.

63 Cf. Thomas Aquinas, Summa theologiae II-II q. 1, a. 9, ad 2.

64 G. Florovskij, Cristo, lo Spirito, la Chiesa, Magnano 1997, p. 25.

65 Ibidem, p. 23.

66 From this point of view, the work of Peter L. Berger is worth a lot of attention: Pytania o wiare. Sceptyczna zachęta do chrześcijaństwa, transl. J. Łoziński, Warszawa 2007. 
Balthasar H.U. von, Credo. Medytacje o Składzie Apostolskim, transl. J.D. Szczurek, Kraków 1997.

Bäumer S., Das Apostolische Glaubensbekenntnis, Mainz 1893.

Biffi I., Teologia, storia e contemplazione in Tommaso d'Aquino, Milano 1995.

Blume C., Das Apostolische Glaubensbekenntnis, Freiburg 1893.

Chenu M.-D., Le plan de la Somme Théologique de S. Thomas, „Revue Thomiste” 45 (139), p. 91-107.

Congar Y., Le sens de l'«Économie» salutaire dans la «théologie» de sant Thomas d'Aquin (Somme theéologique), in: Glaube und Geschichte. Festgabe Joseph Lortz, ed. E. Iserloh, P. Manns, Baden-Baden 1957, p. 73-122.

Credo in Deum $w$ teologii i sztuce Kościołów chrześcijańskich, ed. R. Knapiński,

A. Kramiszewska, Lublin 2009.

Cullmann O., Les premières confessions de foi chrétienne, Paris 1948.

Dokumenty soborów powszechnych, vol. 1: Nicea I, Konstantynopol I, Efez, Chalcedon, Konstantynopol II, Konstantynopol III, Nicea II (325-787), ed. A. Baron, H. Pietras, Kraków 2001 [Źródła Myśli Teologicznej 24].

Dokumenty soborów powszechnych, vol. 4: Lateran V, Trydent, Watykan I (1511-1870), edited by A. Baron, H. Pietras, Kraków 2004 [Źródła Myśli Teologicznej 33].

Dosetti G.L., Il simbolo di Nicea e di Costantinopoli. Edizione critica, Roma-FreiburgBasel-Barcelona-Wien 1967.

Florovskij G., Cristo, lo Spirito, la Chiesa, Magnano 1997.

Ghellinck J. de, Les recherches sur les origines du Symbole des Apôtres, Paris $1949^{2}$.

Hahn A., Hahn G.L., Bibiothek der Symbole und Glaubensregeln der alten Kirche, Breslau $1897^{3}$.

Hardouin J., Acta conciliorum et epistulae decretales, vol. 9, Paris 1714.

Holböck F., Credimus. Kommentar zum Credo Paulus VI, Salzburg-München 1970.

Irenaeus, Adversus haereses.

Justin, 1 apologia.

Katechizm Kościoła katolickiego, Poznań 2002.

Kattenbusch F., Das Apostolische Symbol, vol. 1-2, Leipzig 1894-1900

Kelly J.N.D., Early Christian Creeds, London 1960².

Królikowski J., Miejsce i znaczenie wyznania wiary w liturgii, „Analecta Cracoviensia” 49 (2017), p. 67-80.

Lubac H. de, La foi chrétienne. Essai sur la structure du Symbole des Apôtres, Paris $1970^{2}$. Madoz J., Le symbole du XI concile de Tolède. Ses sources, sa date, sa valeur, Louvain 1938. Menin M., Il fascino dell'emozione, Bologna 2019.

Patfoort A., Thomas d'Aquin, les clés d'une teologie, Paris 1983.

Paweł VI, Wyznanie wiary Ludu Bożego - Credo Populi Dei, tłum. J. Królikowski, Kraków 2012. 
Peri V., Da Oriente e da Occidente. Le Chiese cristiane dall'impero romano all'Europa moderna, a cura di M. Ferrari, vol. 2, Roma-Padova 2002 [Medioevo e Umanesimo 108].

Pouchet J.-R., Vivre la communione dans l'Esprit Saint et dans l'Église. Études sur Basile de Césarée, Abbaye de Bellefontaine 2014.

Sawa R., Marek z Efezu, w: Encyklopedia katolicka, vol. 11, Lublin 2006, c. 1267-1269.

Staats R., Glaubensbekenntnis von Nizäa-Konstantinopel: historische und theologische Grundlagen, Darmstadt 1996.

Studer B., Gott und unsere Erlösung im Glauben der alten Kirchen, Düsseldorf 1985.

Symbol Apostolski w nauczaniu i sztuce Kościoła do Soboru Trydenckiego, ed. R. Knapiński, Lublin 1997.

Thomas Aquinas, In III Sententiarum.

Thomas Aquinas, Summa theologiae

Tomasz z Akwinu [Thomas Aquinas], Dzieła wybrane, transl. J. Salij et al., Kęty 1999.

Keywords: Apostles' Creed, profession of faith, faith, theology, original kerygma, proclamation

\section{SYMBOL WIARY W TEOLOGII I W PRZEPOWIADANIU}

\section{Streszczenie}

Życie Kościoła od samego początku związane jest z poszukiwaniem własnej tożsamości, której wyrazem jest formowanie się wyznania wiary. Świadectwa tego znajdujemy już w Nowym Testamencie, o czym świadczą rozmaite formuły doktrynalne, na których opiera się i które przekazuje przepowiadanie apostolskie. W stosunkowo krótkim czasie te formuły zostały zebrane w jedną całość, najpierw w chrzcielnym wyznaniu wiary, a potem zwłaszcza w wyznaniu wiary nazywanym Symbolem Apostolskim. Zachowuje on swoją wagę i pierwszorzędną rolę w teologii i w przepowiadaniu do naszych czasów, chociaż w praktyce jego rola uległa pomniejszeniu, zwłaszcza w przepowiadaniu. W niniejszym artykule proponuje się powrót do Symbolu Apostolskiego i do jego inspirującego znaczenia. Chodzi przede wszystkim o wydobycie jego przesłania doktrynalnego, które zwraca uwagę na potrzebę całościowego, trynitarno-chrystologicznego, ujmowania zagadnień teologicznych. Taką samą rolę może on odegrać w porządkowaniu dzisiejszego przepowiadania kościelnego, które zachwycając się tak zwanym kerygmatem pierwotnym, popada w krótkowzroczne interpretacje i zawężenia, czego rezultatem jest osłabianie tożsamości chrześcijańskiej.

Słowa kluczowe: Symbol Apostolski, wyznanie wiary, wiara, teologia, kerygmat pierwotny, przepowiadanie 